\title{
A Siberian fungus gnat (Diptera: Mycetophilidae) species found in Estonia
}

\section{Olavi Kurina \& Jostein Kjærandsen}

Kurina, O. \& Kjærandsen, J. 2009: A Siberian fungus gnat (Diptera: Mycetophilidae) species found in Estonia. — Entomol. Fennica 20: 56-60.

The first European record of Exechia inaperta Ostroverkhova, 1979 is presented and its morphological difference from the allied E. exigua Lundström, 1909 is discussed. Diagnostic characters and detailed figures of male terminalia are given for both species. The new finding of E. inaperta in Estonia indicates a possibly disjunct Euro-Siberian distribution pattern of the South-Taiga, also observed in several other species of fungus gnats.

O. Kurina (corresponding author), Institute of Agricultural and Environmental Sciences, Estonian University of Life Sciences, Riia st 181, 51014 Tartu, Estonia; E-mail:olavi@zbi.ee

J. Kjcerandsen, Museum of Zoology, Lund University, Helgonavägen 3, S-223 62 Lund, Sweden; E-mail: jostein.kjaerandsen@zool.lu.se

Received 10 December 2007, accepted 4 February 2008

\section{Introduction}

The genus Exechia Winnertz, 1863 with about 150 species is distributed in all biogeographical regions except Neotropics (Bechev 2000). There are about 70 species known from the Palaearctic region (Søli et al. 2000, Zaitzev 2003), and 44 species in Europe (Chandler 2005). Zaitzev (2003) provided the most comprehensive key, including 51 species from Russia and adjacent areas. Tuomikoski (1966) characterised the species of Exechia as follows: subcosta ending free, $\mathrm{r}_{1} \mathrm{a}$ little if at all longer than $r_{,} r_{5}$ straight, mostly divergent from $\mathrm{m}_{1}, \mathrm{r}-\mathrm{m}$ more than twice as long as the stem of the medial fork, 2-4 propleural bristles present, pale abdominal markings, when present, situated towards bases of the tergites. In northern Europe Exechia species are active throughout the year except midsummer, and they are especially abundant in autumn. Many species are known to hibernate as adults (Väisänen 1981, Kjærandsen 1993, Kurina 1996). All species with known biology are associated with macrofungi at their larval stage (Jakovlev 1994).

In 2005 the first author collected fungus gnats by sweep netting at Piusa in south-eastern Estonia, close to the Estonian-Russian border. The habitat was a wet pine forest with some fallen and decaying trees and several root-systems (Fig. 1). The collecting yielded a great amount of Exechia material. Three specimens were similar to $E$. exigua Lundström, 1909, but belonged to closely allied species not seen before by the authors. After some confusion and discussion, the species proved to be Exechia inaperta Ostroverkhova, 1979, a Siberian fungus gnat not previously reported from Europe. Further collecting nearby the first-mentioned locality in 2007 yielded two more specimens of the species.

Judging from similarities in male terminalia, $E$. inaperta belongs to the E. exigua speciesgroup with at least nine species in the Holarctic region. A revision of this group is being prepared by the second author. The aim of the present com- 
Fig. 1. Collecting locality near Piusa, south-east Estonia.

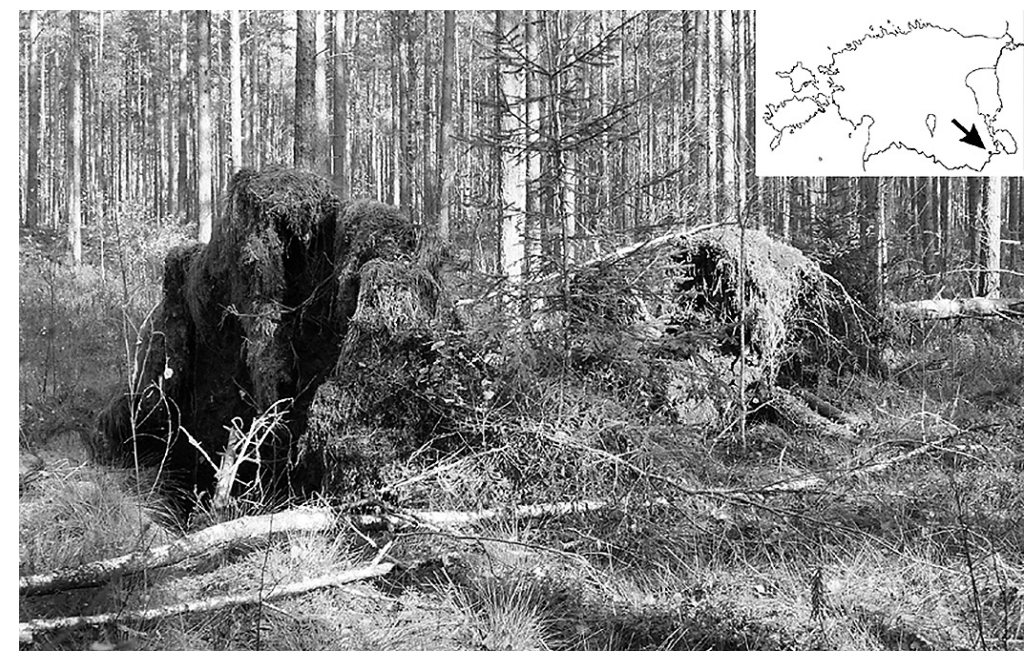

munication is to present the first European record of $E$. inaperta, to diagnose the species and to discuss its difference from E. exigua. Diagnostic characters are based on those found in male terminalia only.

\section{Material and methods}

All material was collected by sweep netting under root-systems of fallen trees and inserted into $70 \%$ alcohol. After sorting the specimens were mounted, following the method described by Vockeroth (1966). The terminalia were detached and treated by a standard method (see Kurina 2006), before being inserted into glycerine. Illustrations of the terminalia were made by the first author using a U-DA drawing tube attached to a Olympus SX31 compound microscope. Adobe Photoshop 5.0 was used to add shading to the illustrations. The morphological terminology of male terminalia follows that of Kjærandsen (2006).

The material is deposited at Institute of Agricultural and Environmental Sciences, Estonian University of Life Sciences, Tartu, Estonia (former Institute of Zoology and Botany) [IZBE], Museum of Zoology, Lund University, Lund, Sweden [MZLU], and Zoological Museum, University of Helsinki, Helsinki, Finland [MZHF].

\section{The species}

\subsection{Exechia inaperta Ostroverkhova, 1979} (Fig. 2 c, d)

Diagnosis. Gonocoxite ventromedially with three strong bristles extending to apex of hypandrial lobe. Hypandrial lobe narrow oblong to slightly spathulate, without setae. Aedeagal guide forming small ovate plate, retracted into gonocoxite. Dorsal branch of gonostylus slightly elongated, with three dark and strong spine-like bristles subapically. Medial branch of gonostylus with two short, blunt spines subapically, with a spine-like strong bristle subbasally on lateral margin, and with a small bristle bearing subbasal punch on internal margin. Ventral branch of gonostylus apically rounded and setose. Internal branch of gonostylus oblong, slightly tapering, apically blunt and possessing two short, spathulate spines, with inferior medially swollen.

Material. ESTONIA, $3 \jmath^{\lambda}$, Piusa $1 \mathrm{~km}-\mathrm{W}$, $\mathrm{N}=57^{\circ} 50$ '26,4' $\mathrm{E}=027^{\circ} 27^{\prime} 08,3$ ', sweep netting,

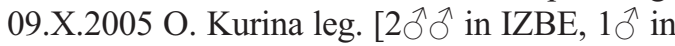
MZLU]; $2 \lesssim ð$, Piusa 2km-SE, N=5750'03,1" $\mathrm{E}=027^{\circ} 29^{\prime} 58,0$ ', sweep netting, 07.X.2007 O. Kurina leg. [IZBE].

\subsection{Exechia exigua Lundström, 1909}

(Fig. 2 a, b)

Diagnosis. Gonocoxite ventromedially bare. Hypandrial lobe acute triangulate, with medial 

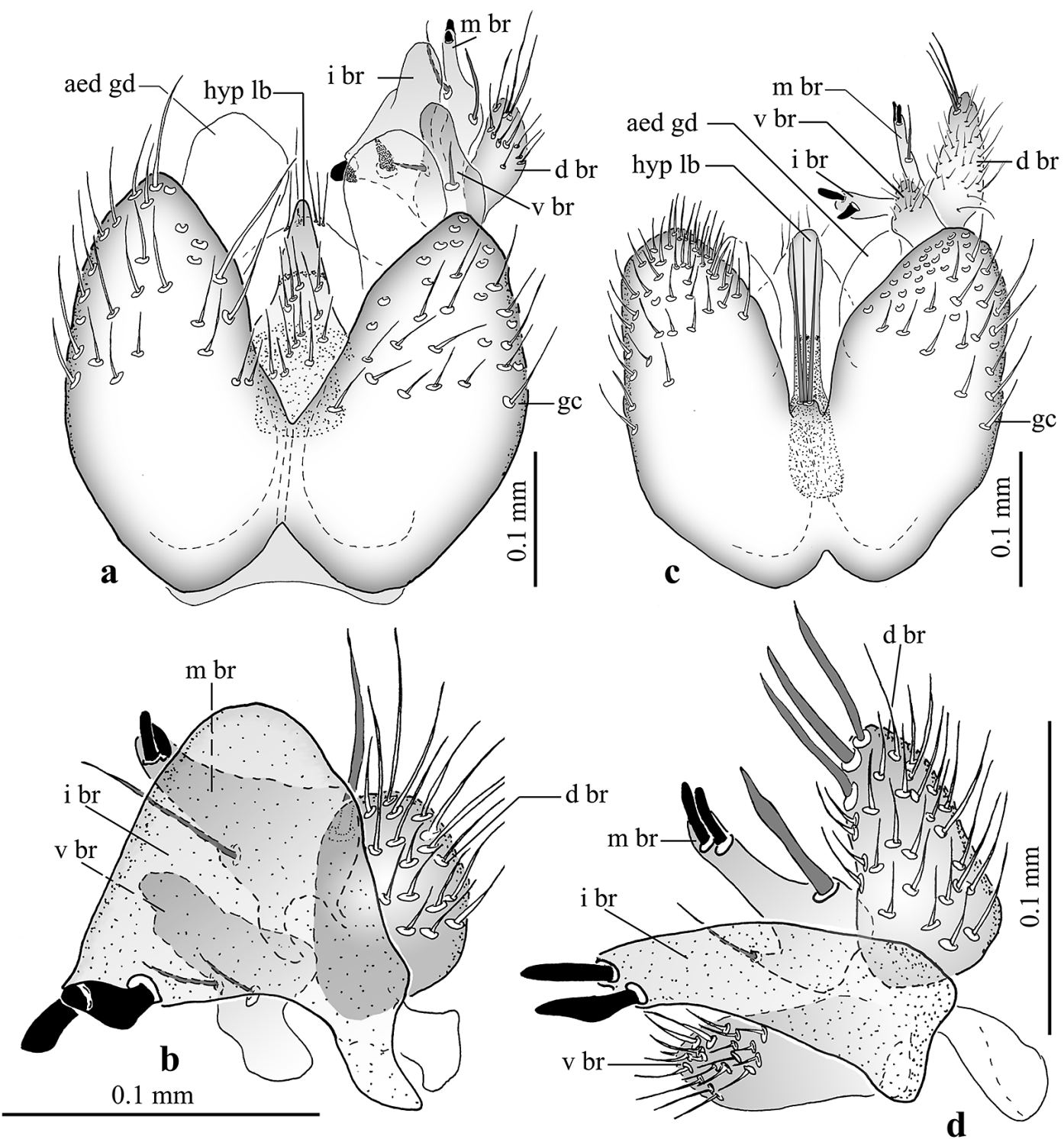

Fig. 2. Male terminalia of Exechia exigua Lundström, 1909 (a, b) and Exechia inaperta Ostroverkhova, 1979 (c, d). - a, c. gonocoxite and gonostylus, ventral view. - b, d. gonostylus, internal view. Abbreviations: aed gd: aedeagal guide, d br: dorsal branch of gonostylus, gc: gonocoxite, hyp lb: hypandrial lobe, i br: internal branch of gonostylus, m br: medial branch of gonostylus, v br: ventral branch of gonostylus.

setae. Aedeagal guide forming large, obovate, exposed plate. Dorsal branch of gonostylus rounded, with bristles of more or less equal size. Medial branch of gonostylus with two short, blunt spines subapically, with a spine-like strong bristle subbasally on lateral margin, and with a bristle on internal margin. Ventral branch of gonostylus narrowed apically (obpyriform), with 23 medial bristles only. Internal branch of gonosty- lus large, subtriangular, possessing two apical short, spathulate spines, with inferior medially swollen and deformed.

Type material studied. Holotype, ô, FINLAND, Ab, Kuustö (Kaarina, Kuusisto), undated, C. Lundström leg. [MZHF]. Original labels: printed label "Kuustö" with a handwritten black crossover; printed label "Lundström"; handwritten label in red ink "E. exigua $\widehat{O}$ L."; 
Table 1. Morphological differences of male terminalia between Exechia inaperta Ostroverkhova, 1979 and Exechia exigua Lundström, 1909.

\begin{tabular}{|c|c|c|}
\hline & E. inaperta & E. exigua \\
\hline $\begin{array}{l}\text { Ventromedial margin } \\
\text { of gonocoxite }\end{array}$ & $\begin{array}{l}\text { With three bristles equally in } \\
\text { length to hypandrial lobe (Fig. } 2 \text { c) }\end{array}$ & Without setae (Fig. 2 a) \\
\hline Hypandrial lobe (hyp lb) & Bare, narrow oblong (Fig. 2 c) & Setose, acute triangulate (Fig. 2 a) \\
\hline $\begin{array}{l}\text { Dorsal branch } \\
\text { of gonostylus ( } \mathrm{d} \text { br) }\end{array}$ & $\begin{array}{l}\text { Elongated, with three strong, } \\
\text { spine-like bristles subapically } \\
\text { (Fig. } 2, \text { d) }\end{array}$ & $\begin{array}{l}\text { Rounded, without extra } \\
\text { strong bristles (Fig. } 2 \text { b) }\end{array}$ \\
\hline $\begin{array}{l}\text { Medial branch } \\
\text { of gonostylus (m br) }\end{array}$ & $\begin{array}{l}\text { Obpyriform, with two short, } \\
\text { blunt spines subapically (Fig. } 2 \text { d) }\end{array}$ & $\begin{array}{l}\text { Nearly triangular, with two } \\
\text { short, blunt spines subapically (Fig. 2, b) }\end{array}$ \\
\hline $\begin{array}{l}\text { Ventral branch } \\
\text { of gonostylus ( } v \text { br) }\end{array}$ & $\begin{array}{l}\text { Apically rounded, setose } \\
\text { (Fig. } 2 \text { d) }\end{array}$ & $\begin{array}{l}\text { Obpyriform, with } 2-3 \\
\text { subbasal bristles only (Fig. } 2 \text { b) }\end{array}$ \\
\hline $\begin{array}{l}\text { Internal branch } \\
\text { of gonostylus (i br) }\end{array}$ & $\begin{array}{l}\text { Oblong, nearly twice as wide } \\
\text { as high, with two short } \\
\text { spathulate spines (Fig. } 2 \text { d) }\end{array}$ & $\begin{array}{l}\text { Humpbacked, subtriangular, } \\
\text { with two short, spathulate } \\
\text { spines (Fig. } 2 \text { b) }\end{array}$ \\
\hline
\end{tabular}

pale green label "Mus. Zool. H:fors Spec. typ. No 4255. Exechia exigua Lundstr." [Mus. Zool Helsinki Loan Nr. D04-1264, remounted on slide by J. Kjaerandsen in 2005].

Additional material. ESTONIA, $2 \hat{\jmath} \hat{\jmath}$, Piusa $1 \mathrm{~km}-\mathrm{W}, \quad \mathrm{N}=57^{\circ} 50^{\prime} 26,4^{\prime \prime} \quad \mathrm{E}=027^{\circ} 27^{\prime} 08,3^{\prime \prime}$, sweep netting, 09.X.2005 O. Kurina leg. [IZBE]; $40{ }^{\wedge} \partial^{\lambda}$, Piusa $1 \mathrm{~km}-\mathrm{W}, \mathrm{N}=57^{\circ} 50 ’ 26,4^{\prime} \mathrm{E}=027^{\circ}$ 27'08,3', sweep netting, 07.X.2007 O. Kurina

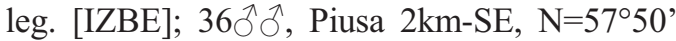
03,1" $\mathrm{E}=027^{\circ} 29^{\prime} 58,0^{\prime}$, sweep netting, 07.X. 2007 O. Kurina leg. [IZBE]. FINLAND: Ka,

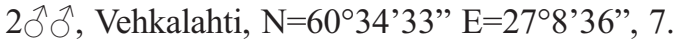
V. 1971 and 29. V. 1971 L. Tiensuu leg. [MZHF]. NORWAY: AK, $1 \mathrm{\jmath}^{\lambda}$, Eidsvoll, in mine galleries at

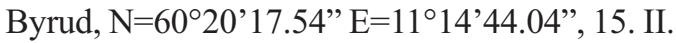
1992 J. Kjærandsen leg. [MZLU]. SWEDEN: LU, $3 \hat{\jmath}$, Jokkmokk, Porsitjärn/Porsi VVO, 1.5 km SE Vuollerim, $\mathrm{N}=66^{\circ} 25^{\prime} 37.99^{\prime}$ ' $\mathrm{E}=20^{\circ} 39^{\prime}$ 48.01”, 60 m a.s.1., 14.IV.-18.X.2003 M. Karström leg. [MZLU].

\section{Discussion}

When describing E. inaperta, Ostroverkhova provided a figure of male terminalia that somewhat differs from the studied material (cf. Ostroverkhova 1979: Fig. 29, 2). The figures of male terminalia of the Estonian material were sent to Mrs. Yulia Maksimova (Tomsk Univer- sity, Russia), who kindly compared them with the holotype material and confirmed the conspecificity. E. inaperta shares with E. exigua the general appearance of male terminalia but differs markedly in details (cf. Table 1 ). In addition, the male terminalia of $E$. inaperta appear to be somewhat smaller than those of E. exigua (cf. Fig. 2 a, c). Furthermore, the studied specimens of $E$. inaperta has pale lateral markings on abdominal tergites II-IV, while E. exigua has clear markings on abdominal tergites II-III only, and only occasionally a hint of lateral marking on tergite IV. According to Ostroverkhova (1979), E. inaperta is somewhat larger than E. exigua, body length $4.5-5 \mathrm{~mm}$ and $2.5-3 \mathrm{~mm}$, respectively. The Estonian material shows no reliable difference in size. The total length of E. inaperta ranges from 3.64 $\mathrm{mm}$ to $4.03 \mathrm{~mm}(\mathrm{n}=4)$, while it ranges from 3.67 $\mathrm{mm}$ to $4.6 \mathrm{~mm}(\mathrm{n}=10)$ in E. exigua.

E. inaperta was previously known by the type material from Tomsk region (Siberia, Russia) only, and appears to be a quite rare in Europe. It has not been found during a large-scale investigation of Nordic Exechia species carried out by the second author (J. Kjaerandsen in prep). The three sweep netting samples (October of 2005 and 2007) from the surroundings of the Piusa village yielded 814 male Exechia specimens belonging to 20 species $-E$. inaperta was represented by five specimens only. E. exigua, on the other hand, is a common Palaearctic species widely distrib- 
uted in Europe (Chandler 2005).

The distribution pattern of $E$. inaperta shows a peculiar character, seemingly with two isolated populations in the western Siberian and southeast Estonia. To draw any conclusions on the distribution of E. inaperta based on the two recording localities only, will be speculative, but it fits nicely into an emerging pattern. Analogically to a distribution pattern found in several moth species, Kurina (1997) characterised Greenomyia mongolica Lastovka \& Matile, 1974 as having a Balto-Eurasian distribution type, connected to spruce and fir forests of the South-Taiga. In recent years several records of eastern Palaearctic fungus gnats species in Europe have been published: e. g., Greenomyia stackelbergi Zaitzev, 1982, G. baikalica Zaitzev, 1994, Boletina takagii Sasakawa \& Kimura, 1974, B. kurilensis Zaitzev, 1994, B. nitiduloides Zaitzev, 1994, Anatella crispa Zaitzev, 1994, Notolopha sibirica Zaitzev \& Maksimova, 2000 (Kurina 1998, Polevoi 2003, Jakovlev et al. 2006, Kjærandsen et al. 2007). All the European records of these species, coming from Fennoscandia and Estonia, are a result of a great upturn in fungus gnats surveys in the region during the last decade. The known records of these species look like the indication of a disjunctive Euro-Siberian distribution pattern. However, as data from intermediate areas of Russia as well as from Eastern Palaearctic (including Siberia) are scanty, several species with an apparent disjunctive pattern of distribution may prove to be transpalaearctic and even Holarctic and circumpolar (see Kjærandsen et al. 2007).

Acknowledgements. We are very thankful to Mrs. Julia Maksimova (Tomsk, Russia) for comparing the figures of E. inaperta male terminalia with the holotype and to Alexei Polevoi (Petrozavodsk, Russia) for intermediating this contact. O. Kurina was partially supported by grant 7558 of Estonian Science Foundation. J. Kjærandsen was financially supported by the Swedish Taxonomy Initiative (see Miller 2005).

\section{References}

Bechev, D. 2000: World distribution of the genera of fungus gnats (Diptera: Sciaroidea, excluding Sciaridae). Studia dipterologica 7(2): 543-552.

Chandler, P. 2005: Fauna Europea: Mycetophilidae. - In: de Jong, H, (ed.): Fauna Europea : Diptera, Nematocera. Fauna Europea version 1. 2. [www document]. URL http://www.faunaeur.org (accessed 19.11.2006).
Jakovlev, E, B. 1994: Palaearctic Diptera associated with fungi and myxomycetes. Petrozavodsk, $127 \mathrm{pp}$. [in Russian, with English summary].

Jakovlev, J., Kjærandsen, J. \& Polevoi, A. 2006: Seventy species of fungus gnats new to Finland (Diptera: Mycetophilidae). - Sahlbergia 11: 22-39.

Kjærandsen, J. 1993: Diptera in mines and other cave systems in southern Norway. — Entomologica Fennica 4: 151-160.

Kjærandsen, J. 2006: Review of fungus gnats of the genus Tarnania Tuomikoski, with a phylogeny of the Rymosia s.l. genus group (Diptera: Mycetophilidae). - Insect Systematics \& Evolution 37: 121-148.

Kjærandsen, J., Hedmark, K., Kurina, O., Polevoi, A., Økland, B. \& Götmark, F. 2007: Annotated checklist of fungus gnats from Sweden (Diptera: Bolitophilidae, Diadocidiidae, Ditomyiidae, Keroplatidae and Mycetophilidae). - Insect Systematics \& Evolution Supplements 65 . 1-127.

Kurina, O. 1996: Hibernation of fungus gnats (Diptera, Mycetophilidae) in Estonian caves. - Studia dipterologica 3: 221-229.

Kurina, O. 1997: Greenomyia mongolica Laštovka et Matile, 1974 (Diptera, Mycetophilidae) found in Estonia. - An International Journal of Dipterological Research 8: 69-71.

Kurina, O. 1998: Fungus gnats in Estonia (Diptera: Bolitophilidae, Keroplatidae, Macroceridae, Ditomyiidae, Diadocidiidae, Mycetophilidae). - Dissertationes Biologicae Universitatis Tartuensis 38, 198 pp.

Kurina, O. 2006: Three new species of Docosia Winnertz (Diptera: Mycetophilidae) from Kazakhstan. - Entomologica Fennica 17: 110-117.

Miller, G. 2005: Linnaeus's Legacy Carries On. — Science 307: 1038-1039.

Ostroverkhova, G. P. 1979: Fungus-gnats (Diptera, Mycetophiloidea) of Siberia. 308 pp. Tomsk [in Russian].

Polevoi, A. 2003: Zoogeographical notes on the Fennoscandian fauna of fungus gnats (Diptera, Mycetophilidae s.1.). - In Heikkilä, R. \& Lindholm, T. (eds.), Biodiversity and conservation of boreal nature: 197-201. Proceedings of the 10 years anniversary symposium of the Nature Reserve Friendship. The Finnish Environment 485, Vantaa, Finland.

Søli, G. E. E., Vockeroth, R. J. \& Matile, L. 2000. A. 4. Families of Sciaroidea. - In Papp, L. \& Darvas, B. (eds.), Contribution to a Manual of Palaearctic Diptera: 49-92. Appendix. Budapest, Science Herald.

Tuomikoski, R. 1966: Generic taxonomy of the Exechiini (Dipt., Mycetophilidae). — Annales Entomologici Fennici 32: 159-194.

Vockeroth, R. 1966: A Method of Mounting Insects from Alcohol. — The Canadian Entomologist 98: 69-70.

Väisänen, R. 1981. Umbelliferous stems as overwintering sites for Mycetophilidae (Diptera) and other invertebrates. - Notulae Entomologicae, 61: 165-170.

Zaitzev, A.I. 2003: Fungus gnats (Diptera, Sciaroidea) of the fauna of Russia and adjacent regions. Part II. - An International Journal of Dipterological Research 14: 77-386. 